\title{
Fluctuation and Re-Establishment of Aerobic Granules Properties during the Long-Term Operation Period with Low-Strength and Low C/N Ratio Wastewater
}

\author{
Lijuan Cha ${ }^{1}$, Yong-Qiang Liu ${ }^{2, *}$, Wenyan Duan ${ }^{1}$, Christain E. W. Sternberg ${ }^{1}{ }^{\mathbb{D}}$, Qiangjun Yuan ${ }^{1,3}$ \\ and Fangyuan Chen ${ }^{1, *}$ \\ 1 Yunnan Key Lab of Soil Carbon Sequestration and Pollution Control, Faculty of Environmental Science and \\ Engineering, Kunming University of Science and Technology, Kunming 650500, China; \\ eseyjb@kust.edu.cn (L.C.); duanwenyan0405@gmail.com (W.D.); christian_ew_steinberg@web.de (C.E.W.S.); \\ a1217100592@hotmail.com (Q.Y.) \\ 2 Faculty of Engineering and Physical Sciences, University of Southampton, Southampton SO17 1BJ, UK \\ 3 Institute of Biology, Humboldt Universität zu Berlin, 10115 Berlin, Germany \\ * Correspondence: Y.Liu@soton.ac.uk (Y.-Q.L.); chenfy@kust.edu.cn (F.C.)
}

check for updates

Citation: Cha, L.; Liu, Y.-Q.; Duan, W.; Sternberg, C.E.W.; Yuan, Q.; Chen, F. Fluctuation and Re-Establishment of Aerobic Granules Properties during the Long-Term Operation Period with Low-Strength and Low C/N Ratio Wastewater. Processes 2021, 9, 1290. https://doi.org/10.3390/ pr9081290

Academic Editor: Bipro R. Dhar

Received: 26 June 2021

Accepted: 23 July 2021

Published: 26 July 2021

Publisher's Note: MDPI stays neutral with regard to jurisdictional claims in published maps and institutional affiliations.

Copyright: (C) 2021 by the authors Licensee MDPI, Basel, Switzerland. This article is an open access article distributed under the terms and conditions of the Creative Commons Attribution (CC BY) license (https:// creativecommons.org/licenses/by/ $4.0 /)$.

\begin{abstract}
Long-term structure stability of aerobic granules is critical to maintaining stable wastewater treatment performance. In this study, granulation and long-term stability of sludge-treating synthetic wastewater with a low chemical oxygen demand to nitrogen (COD/N) ratio of 4:1 and COD concentration of $400 \mathrm{mg} / \mathrm{L}$ in anoxic-oxic conditions were investigated for over 300 days. Inoculated suspended sludge gradually transformed into granules-dominant sludge on day 80. Due to the improved sludge volume index after $30 \mathrm{~min}$ settling $\left(\mathrm{SVI}_{30}\right)$, mixed liquor suspended solids (MLSS) reached $5.2 \mathrm{~g} / \mathrm{L}$ on day 140 . Without any external intervention or disturbance, aerobic granules started to disintegrate from day 140, causing the increase in SVI and the decrease in biomass concentration until day 210, with the average sludge size reduced to $243 \mu \mathrm{m}$. From day 210, granular sludge started to be re-established by re-granulation, and the average granule size increased to $500 \mu \mathrm{m}$ on day 302. During these disintegration and re-granulation periods, there was no obvious difference in terms of COD removal and nitrification, but microbial species were found more diverse after the re-granulation, with Thauera and Sphingomonas dominant. Although there was no external intervention, the food to microorganisms ratio $(\mathrm{F} / \mathrm{M})$ varied significantly due to the changes in biomass concentration caused by strong selective pressure and the change of sludge-settling ability in the reactor. F/M ratios should be controlled between 0.3 and $1.0 \mathrm{gCOD} / \mathrm{gSS} \cdot \mathrm{d}$ to maintain the stable structure of granules to minimize the fluctuation of sludge properties under the conditions used in this study. Although aerobic granular sludge is able to re-establish itself after disintegration, controlling F/M ratios in a certain range would benefit long-term stability. The findings in this study are significant to deepen the understanding of granule stability with low-strength and low COD ratio wastewater and, thus, provide guidance for maintaining the long-term stability of granules.
\end{abstract}

Keywords: aerobic granules; low carbon to nitrogen ratio; disintegration; re-granulation; long-term stability; F/M ratio

\section{Introduction}

Aerobic granular sludge is a promising technology to replace conventional activated sludge for biological wastewater treatment. More than 60 full-scale aerobic granules-based wastewater treatment facilities worldwide have been built and operated, but its commercial application speed is not as fast as expected. One of the reasons for this is that the longterm stability of granules has still not been fully understood. Compared with granulation or start-up of granules-based reactors or treating different types of wastewater such as industrial wastewater, nutrients, heavy metals, and many toxic substances [1-6], studies 
on the stability of granules are more challenging because reactors have to be operated and maintained for a long time with sufficient resources. Considering the importance of the long-term stability of granules for practical application, this study aimed to investigate the long-term stability of granules.

Suspended sludge can easily transform into compact granular sludge under selective pressure such as short settling time [7] and a high exchange ratio [4] in sequential batch reactors (SBRs). With more studies on the formation of granules, the granulation speed has been greatly increased. Liu and Tay (2015) reported that the optimal conditions for granulation and long-term stability were different [8], implying that results and conclusions from granulation studies might not be applicable to maintenance of the long-term stability of granules. Thus, it is imperative to investigate the long-term stability of granules from different perspectives.

Instability of granules was observed and reported even in short-time operation periods, such as less than 3 months. Different types of instability of granules were observed under different operational conditions such as the conversion of compact granules to fluffy granules with filamentous overgrowth [9], the out-competition of flocs over formed granules [10], or the disintegration of formed granules into fragments or pieces [11]. It can thus be speculated that the mechanisms of instability of granules under different conditions might be quite different. This further poses challenges to studies on the long-term stability of granules because granule stability might be closely related to the conditions applied to reactors such as wastewater type, reactor operational conditions, $\mathrm{pH}$, and temperature. To interpret the phenomenon of granule instability, efforts have been put to explain the possible reasons. It was speculated that over-increased granule size with limited oxygen transfer into granules could result in anaerobic cores inside, which might lead to the disintegration of granules [12]. In addition, microbial community change under favorable conditions for algae and filamentous overgrowth but unfavorable conditions for functional organisms to excrete sufficient EPS could lead to the instability of granules [13]. The overgrowth of flocs in reactors occurs when flocs develop good settling ability and cannot be washed out by strong selective pressure timely. This would lead to the dominance of flocs and gradual deterioration of sludge-settling properties [10]. To enhance granule stability, many strategies were proposed and tested in laboratory-scale experiments such as applying some operational conditions to suppress the activity of anaerobes to strengthen granule core or some types of wastewater with high ammonium or phosphorus contents for enriching slow-growing microorganisms, such as nitrifying bacteria or phosphorusaccumulating organisms in granules [14]. Recently, some studies even applied external measures to strengthen the stability of aerobic granules with the aid of chemicals such as metal cations or materials such as carbon fibers $[15,16]$. However, these measures would result in increased operating costs and unsustainable wastewater treatment. The strategy of selecting slow-growing microbial bacteria such as nitrifying bacteria and phosphorusaccumulating organisms to stabilize granules is highly dependent on the composition of wastewater used (i.e., if wastewater contains nitrogen [17] or phosphorus [18] and how much it contains), which cannot be changed at all in practice. Moreover, there are different types of wastewater with different $\mathrm{N}$ and $\mathrm{P}$ concentrations, different COD/N and COD/P ratios, and different levels of readily or non-readily biodegradable CODs, which might lead to the different long-term stability of granules and are, thus, worth investigation. Pronk et al. (2015) found that an anaerobic phase prior to the aeration phase for the uptake of easily biodegradable substrates could improve the stability of granules when treating wastewater primarily containing easily biodegradable COD [19].

Essentially, the stability of granules is determined by the microbial population under specific operational conditions and the specific type of wastewater treated. For the treatment of wastewater with both COD and $\mathrm{N}$, the ratio between heterotrophic and autotrophic nitrifying populations in granules might be governed by the COD/N ratio $[2,20,21]$. Liu et al. (2004) reported that a lower COD/N favors the formation of smaller and more compact granules with greater hydrophobicity [17]. However, whether smaller 
and more compact granules could maintain long-term stability is still unclear regarding long-term inhibition from free ammonia and free nitrous acid [22,23]. Therefore, many experiments have attempted to determine the optimal ratios of COD/N for both good performance and robust aerobic granules [11,24-26]. For instance, Wu et al. (2012) found that the aerobic granules were successfully cultivated in a totally aerobically operated system with a $\mathrm{C} / \mathrm{N}$ ratio of $1: 1$ and 2:1, respectively, while no granules were formed in reactors with no carbon addition or $\mathrm{C} / \mathrm{N}$ ratio of 4:1 within a 30-day operation [25]. Luo et al. (2014) investigated the stability of aerobic granules in aerobic operation with the feeding of a $\mathrm{C} / \mathrm{N}$ ratio of 4,2 , and 1 , respectively, over 100 days, and found that the substrate with the $\mathrm{C} / \mathrm{N}$ ratio of 2 and 1 strongly decreased stability of the granules due to the significant reduction of extracellular polymers substances (EPS) [11]. Kocaturk et al. (2016) indicated that a low $\mathrm{COD} / \mathrm{N}$ range of $2-5$ led to stable, small, and dense granules enriched in slow-growing nitrifiers, while the optimal COD/N ratio was found to be 7.5 in terms of high COD and nitrogen removal [21]. The results from these studies are contradictory and hard to draw a consistent conclusion, which is mainly because the operational conditions in each study were different. Furthermore, the reactor operation periods in these studies were not long enough, being usually less than 100 days and with some as short as 30 days. Such short operational periods provide very limited information for the long-term stability of granules, a critical factor in the real world. Nevertheless, it has been claimed that nitrifying bacteria are beneficial to the stability of granules.

In this study, we thus aimed to investigate the long-term structural stability of aerobic granules treating low-strength wastewater with a low COD/N ratio of 4:1 with enriched nitrifying bacteria by operating the reactor for at least 300 days. Meanwhile, microbial communities of sludge on different days were examined to understand the microbial population shift in granules when they become unstable. It was expected that this study would provide useful information regarding the long-term stability of granules with enriched nitrifying bacteria inside, key factors affecting the long-term stability of this type of granules, and the possible mechanism involved.

\section{Materials and Methods}

\subsection{Experiment Setup and Operation}

A bubble column with an internal diameter of $5 \mathrm{~cm}, \mathrm{H} / \mathrm{D}$ (height/diameter) ratio of 20, and a working volume of $2 \mathrm{~L}$ was used as a reactor in this study for granulation and long-term operation. The reactor was operated sequentially with a cycle time of $4 \mathrm{~h}$, including $5 \mathrm{~min}$ of anaerobic influent filling from the top port of the reactor, $1 \mathrm{~min}$ of mixing with a low aeration rate at $1 \mathrm{~L} / \mathrm{min}, 54 \mathrm{~min}$ of static condition with no mixing, 145 to $170 \mathrm{~min}$ of aeration, 30 to $5 \mathrm{~min}$ of settling, and $5 \mathrm{~min}$ of effluent discharging. The influent filling volume was set as $1 \mathrm{~L}$. Settling time was set as $30 \mathrm{~min}$ at the outset, and then it was gradually reduced to 5 min within 40 days. The effluent was discharged from the middle port of the reactor with a volumetric exchange ratio of $50 \%$. Fine air bubbles were supplied through an air sparger at the reactor bottom with an airflow rate of $2 \mathrm{~L} / \mathrm{min}$ for aeration. Activated sludge from a local domestic wastewater treatment plant was seeded in the reactor for the cultivation of the aerobic granules.

\subsection{Media}

A synthetic wastewater with the following compositions was used for the cultivation of granules: sodium acetate, $\left(\mathrm{NH}_{4}\right)_{2} \mathrm{SO}_{4}, \mathrm{KH}_{2} \mathrm{PO}_{4}, \mathrm{NaHCO}_{3}$, and micronutrients. Sodium acetate and $\left(\mathrm{NH}_{4}\right)_{2} \mathrm{SO}_{4}$ provided a carbon source and nitrogen source, respectively, while $\mathrm{NaHCO}_{3}$ provided an inorganic carbon source and $\mathrm{pH}$ control for nitrification. COD and $\mathrm{NH}_{4}{ }^{+}-\mathrm{N}$ concentrations in the influent were set at 400 and $100 \mathrm{mg} / \mathrm{L}$, respectively, to maintain a COD/ $\mathrm{N}(\mathrm{C} / \mathrm{N})$ ratio of $4: 1$, an organic loading rate $(\mathrm{OLR})$ of $1.2 \mathrm{~kg} \mathrm{COD} / \mathrm{m}^{3} \cdot \mathrm{d}$, and a nitrogen loading rate (NLR) of $0.3 \mathrm{~kg} \mathrm{~N} / \mathrm{m}^{3} \cdot \mathrm{d}$ in the reactor. The influent also contained micronutrients of $\mathrm{CaCl}_{2} \cdot 2 \mathrm{H}_{2} \mathrm{O} 25 \mathrm{mg} \mathrm{L}-1, \mathrm{MgSO}_{4} \cdot 7 \mathrm{H}_{2} \mathrm{O} 20 \mathrm{mg} \mathrm{L}^{-1}, \mathrm{FeSO}_{4} \cdot 7 \mathrm{H}_{2} \mathrm{O}$ $10 \mathrm{mg} \mathrm{L}^{-1}$, EDTA-2Na $10 \mathrm{mg} \mathrm{L}^{-1}, \mathrm{MnCl}_{2} \cdot 4 \mathrm{H}_{2} \mathrm{O} 0.12 \mathrm{mg} \mathrm{L}{ }^{-1}, \mathrm{ZnSO}_{4} \cdot 7 \mathrm{H}_{2} \mathrm{O} 0.12 \mathrm{mg} \mathrm{L}^{-1}$, 
$\mathrm{CuSO}_{4} \cdot 5 \mathrm{H}_{2} \mathrm{O} 0.03 \mathrm{mg} \mathrm{L}^{-1},\left(\mathrm{NH}_{4}\right)_{6} \mathrm{Mo}_{7} \mathrm{O}_{24} \cdot 4 \mathrm{H}_{2} \mathrm{O} 0.05 \mathrm{mg} \mathrm{L}^{-1}, \mathrm{NiCl}_{2} \cdot 6 \mathrm{H}_{2} \mathrm{O} 0.1 \mathrm{mg} \mathrm{L}^{-1}$, $\mathrm{CoCl}_{2} \cdot 6 \mathrm{H}_{2} \mathrm{O} 0.1 \mathrm{mg} \mathrm{L}^{-1}, \mathrm{AlCl}_{3} \cdot 6 \mathrm{H}_{2} \mathrm{O} 0.05 \mathrm{mg} \mathrm{L}^{-1}$, and $\mathrm{H}_{3} \mathrm{BO}_{3} 0.05 \mathrm{mg} \mathrm{L}^{-1}$.

\subsection{Analytical Methods}

$\mathrm{COD}, \mathrm{NH}_{4}{ }^{+}-\mathrm{N}, \mathrm{NO}_{2}{ }^{-}-\mathrm{N}, \mathrm{NO}_{3}{ }^{-}-\mathrm{N}$, sludge volume index (SVI), mixed liquor suspended solids (MLSS), and mixed liquor volatile suspended solids (MLVSS) were analyzed in accordance with standard methods (APHA 1998). Average particle size was determined by a laser particle size analysis system with a measuring range from 0 to $2000 \mu \mathrm{m}$ (Malvern MasterSizer Series 2600, Malvern Instruments Ltd., Malvern, UK). The volume percentage of the sludge with a mean size below $200 \mu \mathrm{m}$ (SVP-SB200) was calculated by the sum of the volume percentages of the granules with particle sizes smaller than $200 \mu \mathrm{m}$, which can be read directly from the analysis report of the test. Morphology of the aerobic granules was observed by optical microscope and a digital camera (Leica Microsystems Wetzlar GmbH.DM100.DEU).

$30 \mathrm{~mL}$ of the mixed liquor from the reactor was collected for DNA extraction. Both polymerase chain reaction (PCR) amplification of the extracted bacterial 16S rRNA gene and denaturing gradient gel electrophoresis (DGGE) were conducted based on methods described elsewhere [27]. The extracted DNA was used as the template for PCR amplification (Bio-Rad, Hercules, CA, USA). For the bacterial species, the variable V3 region of the $16 \mathrm{~S}$ rDNA was amplified using primers 357f-GC ( $5^{\prime}$-CCTACGGGAGGCAGCAG-3 ${ }^{\prime}$ ) and 518r (5'-ATT ACC GCG GCT GCT GG-3'). Amplification began with an initial denaturation at $94{ }^{\circ} \mathrm{C}$ for $4 \mathrm{~min}$, followed by 30 cycles of denaturation at $94{ }^{\circ} \mathrm{C}$ for $0.5 \mathrm{~min}$, annealing at $56{ }^{\circ} \mathrm{C}$ for $1 \mathrm{~min}$ and extension at $72{ }^{\circ} \mathrm{C}$ for $0.5 \mathrm{~min}$. It ended with a final elongation step at $72{ }^{\circ} \mathrm{C}$ for $7 \mathrm{~min}$. The PCR-amplified DNA products were separated via DGGE, and the DGGE images were acquired using ChemiDoc (Bio-Rad). Clear and intense bands in the DGGE gel were excised for DNA sequencing. The nucleotide sequences were compared with the sequences in GeneBank using the BLAST program to identify microbial species.

\section{Results and Discussion}

3.1. Granule Formation, Disintegration, and Re-Establishment during the Long-Term Operation Period

Figure 1 shows the biomass concentration and SVI over a long-term operation period. It was found that SVI increased during the first 40 days, resulting in reduced biomass concentration to $1.2 \mathrm{~g} / \mathrm{L}$. From day 40, $\mathrm{SVI}_{30}$ began to decrease gradually from $180 \mathrm{~mL} / \mathrm{g}$ until $41 \mathrm{~mL} / \mathrm{g}$ on day 140 . During this period, the ratios of $\mathrm{SVI}_{30} / \mathrm{SVI}_{5}$ increased from 0.5 to 1 on day 80 . It is generally believed that an $\mathrm{SVI}_{30} / \mathrm{SVI}_{5}$ ratio close to 1 indicates the dominance of granular sludge; thus, day 80 was deemed to have a complete transformation of suspended sludge to granular sludge.

SVI is closely related to sludge settleability. A lower SVI represents a higher sludge settleability, which can lead to the retention of sludge in SBRs, while a higher SVI can result in biomass washout. Selective pressure is a pre-condition to retain sludge with a high settling ability while washing out sludge with a poor settling ability for granulation in SBRs. It was observed that the biomass concentration decreased with the increase in SVI and increased steeply after granules formed from day 80 . Biomass concentration reached $5.2 \mathrm{~g} / \mathrm{L}$ on day 140, as shown in Figure 1. In addition, it was noted that the ratio of MLVSS to MLSS gradually increased from around $60 \%$ in the seed to $97 \%$ in the granules due to little inorganic solids in the influent and no inorganic precipitation induced during the biological treatment process. 



Figure 1. Characteristics of the sludge during the long-term operation period: (A) Biomass concentration and MLVSS/MLSS; (B) $\mathrm{SVI}_{30}$ and $\mathrm{SVI}_{30} / \mathrm{SVI}_{5}$.

SVI can also be used to indicate the stability of granules. It was observed that after granulation, SVI started to increase from $40 \mathrm{~mL} / \mathrm{g}$ on day 140 and then fluctuated between 80 and $100 \mathrm{~mL} / \mathrm{g}$ until day 210, suggesting the deterioration of the granules' settling ability and instability of granules properties. Consequently, MLSS decreased sharply from 5.2 to $3.6 \mathrm{~g} / \mathrm{L}$ from day 140 to day 150 due to deteriorated sludge setting ability and biomass retention. From day 190, the biomass dropped again until the lowest MLSS value of $2.2 \mathrm{~g} / \mathrm{L}$ on day 210. However, from day 210, $\mathrm{SVI}_{30}$ decreased gradually, and MLSS increased correspondingly due to increased sludge-settling ability and biomass retention. MLSS reached $7 \mathrm{~g} / \mathrm{L}$ on day 270 . After that, the biomass concentration decreased again, and MLSS reduced to $4.7 \mathrm{~g} / \mathrm{L}$ on day 290. In an aerobic granular sludge reactor, the biomass concentration was not controlled. After MLSS reached $7 \mathrm{~g} / \mathrm{L}$ due to the low SVI of the granular sludge, a decrease in biomass concentration was observed that was quite similar to the decrease in biomass concentration on the operation day of around 130. This could be a sign that the granule sludge might disintegrate again, probably from $\mathrm{DO}$ restriction due to high biomass concentration. The fluctuations of sludge property in terms of SVI and biomass concentration indicate that the granular sludge was unstable during the long-term operation period but that the granular sludge's settling ability could be re-established without any external intervention.

The size of aerobic granular sludge is another important indicator to describe the stability of granules. Figure 2A shows the size distribution of aerobic granules during the whole operation period. The mean size of the granules gradually increased to $471 \mu \mathrm{m}$ on day 140. Then, the granules were found disintegrated on around day 190 to fragments and suspended sludge (i.e., flocs) was observed. It has been reported that flocs always outcompete granules in terms of growth, but a selective washout of flocs under a short settling time benefits the stability and dominance of granules in reactors [10]. Meanwhile, it was observed that a few granules that did not disintegrate became fluffy with the growth of filamentous organisms. Due to this, the mean size of the granules decreased to $243 \mu \mathrm{m}$ on day 210. However, it recovered with an increase to $413 \mu \mathrm{m}$ on day 272 and $500 \mu \mathrm{m}$ on day 302 , respectively. Figure 2B shows the volume percentage of the sludge with a mean size 
below $200 \mu \mathrm{m}$ (SVP-SB200) in the granule disintegration period. SVP-SB200 increased from $16 \%$ on day 140 to $40 \%$ on day 210 . With the re-granulation of the sludge, the SVP-SB200 value gradually decreased to $20 \%$ (day 272 ) and $15 \%$ (day 300), respectively. These results confirm the disintegration and re-formation of the granules.

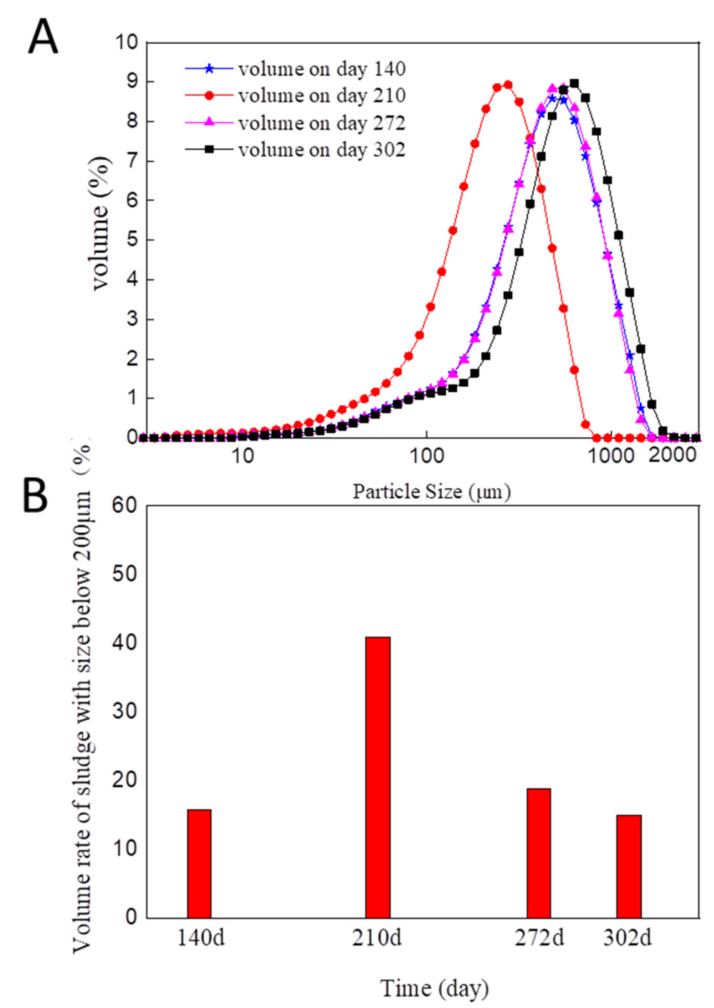

Figure 2. Size distribution of the aerobic granules during the long-term operation period: (A) Particle size distribution; (B) volume of sludge with size below $200 \mu \mathrm{m}$.

It needs to be pointed out that no operational conditions were changed during this period; therefore, the disintegration and re-formation of granules is a kind of self-regulation of sludge under the operational conditions. Although there was no change in operational conditions, the formation of the granules and retention of granules in the reactor due to increased settling ability led to the changes in biomass concentration in the reactor, $\mathrm{F} / \mathrm{M}$ ratio, feast and famine ratio, and sludge retention time (SRT). Selection pressure from settling time is the key to form granules, but it is not the only factor to maintain the stability of granular sludge during the long-term operation period. The large fluctuation of the biomass concentration could be the essential factor that led to the disintegration and re-formation of the granules because the biomass concentration determines F/M ratios, the feast/famine ratio, and SRT in the reactor.

\subsection{The Removal Performance of COD and Ammonium-Nitrogen during the Long-Term Operation Period with Varying Sludge Characteristics}

Figure 3 shows the performance of sludge during the long-term operation period. The COD removal efficiency was approximately $90 \%$ throughout the whole operation period; however, ammonium removal efficiency fluctuated significantly. While ammonia removal efficiency was $99 \%$ during the first month, it decreased sharply to $50 \%$ as the biomass concentration fell, most likely due to a loss of nitrifying bacteria through washout of the sludge. On day 60 , ammonium removal efficiency gradually returned to $99 \%$ due to the increase in biomass concentration and re-accumulation of the nitrifying bacteria in the sludge. It can be seen from Figure 3 that ammonium was converted to nitrate during most of the operation period, except for those 30 days with low ammonium removal efficiency 
during which ammonium was oxidized to nitrite due to insufficient accumulation of nitrite-oxidizing bacteria in the sludge.


Figure 3. Performances of the aerobic granules during the long-term operation period: (A) COD removal; (B) ammonia removal; (C) nitrite production; (D) nitrate production.

Figure 4 shows the cycle profile of granules on day 92 with a low biomass concentration of $2.1 \mathrm{~g} / \mathrm{L}$ and day 237 with a high biomass concentration of $4.0 \mathrm{~g} / \mathrm{L}$. It can be seen that both COD and ammonium were totally removed, and complete nitrification was achieved in both cycles. Based on the cycle analysis and biomass concentration, the specific removal rates of COD in the anaerobic phase, the specific removal rate of ammonium, and the specific production rate of nitrate in the aerobic phase on these two days were calculated and shown in Figure 5. It can be seen that all the specific rates on day 237 were greatly lower than those on day 92, which indicates that nitrifying microorganisms enriched in the reformed granules were less than those in the granules formed directly from activated sludge. Even so, the sludge is good enough to achieve complete nitrification.

\subsection{Microbial Community Analysis of Sludge during the Periods with Granule Disintegration and Re-Establishment}

To understand the microbial community structure of granular sludge before disintegration and after re-granulation, DGGE of samples on days 85 (i.e., before disintegration) and 227 (i.e., after re-granulation) were conducted by excising 10 dominant DGGE bands, PCR amplification, and DNA sequencing to identify the dominant microbial species. Table 1 shows the microbial species of the main DGGE bands from the granules on days 85 and 227 , respectively, which represented dominant microbial species in the granular sludge. It can be seen that there was a shift in the dominant microbial species in the granules before the disintegration and after the re-granulation, although sludge in the reactor was present in the form of granules. In addition, it is noted that all dominant microorganisms were aerobic and facultative on these two days. It is most likely that granule size in most of the 
operation period was below $500 \mu \mathrm{m}$ and, thus, it was challenging to create anaerobic cores in granules when air supply was sufficient and the influent COD concentration was low. In addition, even if there were anaerobic bacteria present in granules, they were not dominant to be detected.

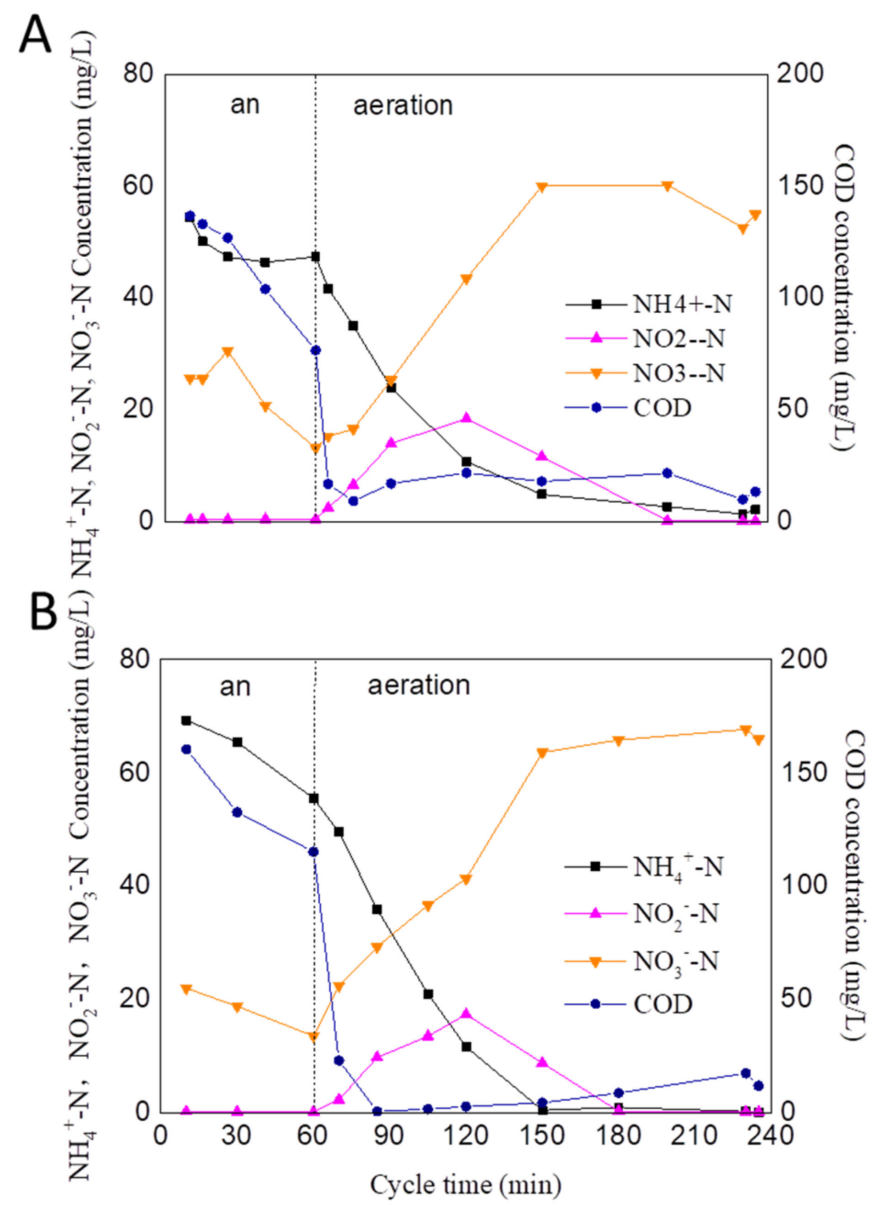

Figure 4. Profiles of $\mathrm{NH}_{4}{ }^{+}-\mathrm{N}, \mathrm{NO}_{2}{ }^{-}-\mathrm{N}$, and $\mathrm{NO}_{3}{ }^{-}-\mathrm{N}$ concentrations in batch cycles: (A) On day 92 with MLSS of $2.1 \mathrm{~g} / \mathrm{L} ;(\mathbf{B})$ on day 237 with MLSS of $4.0 \mathrm{~g} / \mathrm{L}$.

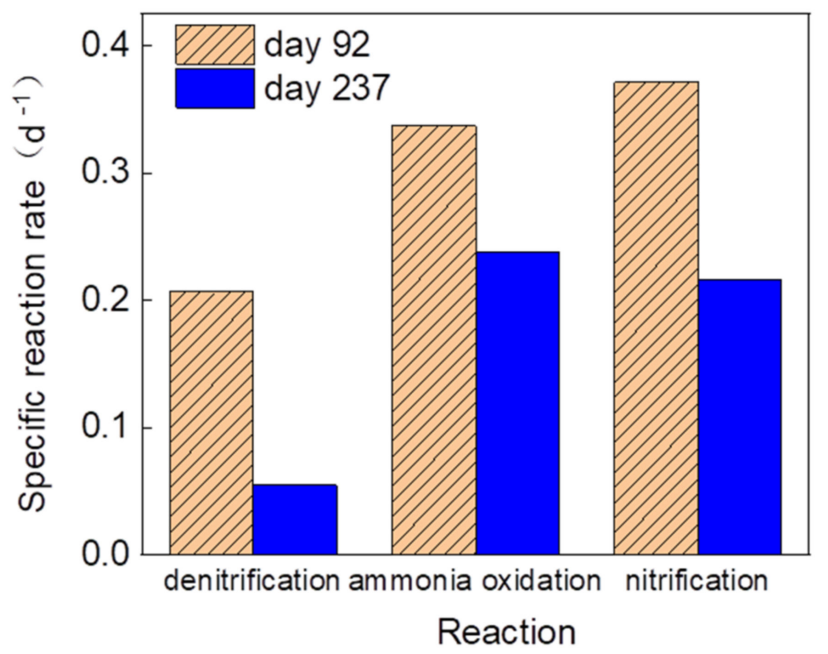

Figure 5. Specific nitrification and denitrification rates of aerobic granules in cycles on days 92 and 237. 
Table 1. DGGE band sequencing analysis on day 85 and 227.

\begin{tabular}{|c|c|c|c|c|c|c|c|c|c|c|c|}
\hline \multirow{3}{*}{ Bd } & \multicolumn{5}{|c|}{ Day 85} & \multicolumn{6}{|c|}{ Day 227} \\
\hline & \multirow{2}{*}{$\begin{array}{l}\text { Closest Relatives in GenBank } \\
\text { (Accession no.) }\end{array}$} & \multirow{2}{*}{$\underset{(\%)}{\text { Similarity }}$} & \multicolumn{3}{|c|}{ Classification } & \multirow{2}{*}{ Bd } & \multirow{2}{*}{$\begin{array}{l}\text { Closest Relatives in } \\
\text { GenBank (Accession no.) }\end{array}$} & \multirow{2}{*}{$\underset{(\%)}{\operatorname{Similarity}}$} & \multicolumn{3}{|c|}{ Classification } \\
\hline & & & Genus & Family & Phylum & & & & Genus & Family & Phylum \\
\hline 1 & Hydrogenophaga sp. KMM 6726 & 100 & Hydrogenophaga & Comamonadaceae & Proteobacteria & 1 & Acinetobacter sp. XJ127 & 100 & \multirow{3}{*}{$\begin{array}{c}\text { Acinetobacter } \\
\text { Nitrosomonas } \\
\text { Bdellovibrio }\end{array}$} & \multirow{3}{*}{$\begin{array}{l}\text { Moraxellaceae } \\
\text { Nitrosomonadaceae } \\
\text { Bdellovibrionaceae }\end{array}$} & Proteobacteria \\
\hline 2 & Thauera sp. G3DM-88 & 100 & Thauera & Rhodocyclaceae & Proteobacteria & 2 & \multirow{3}{*}{$\begin{array}{l}\text { Uncultured bacterium } \\
\text { Novosphingobium tardaugens } \\
(\mathrm{T})\end{array}$} & 100 & & & Proteobacteria \\
\hline 3 & Thauera sp. CJSOPY1 (T-IV) & 100 & Thauera & Rhodocyclaceae & Proteobacteria & 3 & & 95.1 & & & Proteobacteria \\
\hline 4 & bacterium G14(AY345397) & 92 & Acidovorax & Comamonadaceae & Proteobacteria & 4 & & 100 & \multirow{4}{*}{$\begin{array}{l}\text { Novosphingobium } \\
\text { Unclassified_- } \\
\text { "Saprospiraceee" } \\
\text { Sphingopyxis } \\
\text { Thauera }\end{array}$} & Sphingomonadaceae & Proteobacteria \\
\hline 5 & Thauera sp. CJSOPY1 (T-IV) & 96.3 & Thauera & Rhodocyclaceae & Proteobacteria & 5 & Uncultured bacterium & 100 & & Saprospiraceae & Bacteroidetes \\
\hline $\begin{array}{l}6 \\
7\end{array}$ & $\begin{array}{l}\text { Uncultured Leadbetterella sp. } \\
\text { Thauera sp R-26885 }\end{array}$ & 100 & Leadbetterella & Cytophagaceae & Bacteroidetes & 6 & Sphingopyxis baekryungensis & 84.0 & & \multirow{2}{*}{$\begin{array}{l}\text { Sphingomonadaceae } \\
\text { Rhodocyclaceae }\end{array}$} & \multirow{2}{*}{$\begin{array}{l}\text { Bacteroidetes } \\
\text { Proteobacteri }\end{array}$} \\
\hline 8 & 1nauera sp. 1-20003 & 100 & Thauera & S ronoc yctacene & Proteobacteria & 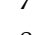 & Thauera sp. CJSOPY1 (T-IV) & 100 & & & \\
\hline$\gamma$ & Uncultured Thauera sp. & 100 & Thauera & Rhodocyclaceae & Proteobacteria & 8 & Uncultured bacterium & 100 & \multirow{4}{*}{$\begin{array}{l}\text { Unclassitied_- } \\
\text { Cytophagales } \\
\text { Thauera } \\
\text { Thauera } \\
\text { Hyphomicrobium }\end{array}$} & Cytophagaceae & Bacteroidetes \\
\hline 9 & Thauera sp. CJSOPY1 (T-IV) & 100 & Thauera & Rhodocyclaceae & Proteobacteria & 9 & Thauera aromatica & 100 & & \multirow{3}{*}{$\begin{array}{l}\text { Rhodocyclaceae } \\
\text { Rhodocyclaceae } \\
\text { Hyphomicrobiaceae }\end{array}$} & \multirow{3}{*}{$\begin{array}{l}\text { Proteobacteria } \\
\text { Proteobacteria } \\
\text { Proteobacteria }\end{array}$} \\
\hline 10 & Uncultured bacteria & 100 & Thauera & Rhodocyclaceae & Proteobacteria & 10 & $\begin{array}{l}\text { Thauera aromatica } \\
\text { S }\end{array}$ & $\begin{array}{c}96.3 \\
92\end{array}$ & & & \\
\hline & & & & & & 11 & Hyphomicrobium sp. PMC & 92 & & & \\
\hline
\end{tabular}

Note: Bd, band. 
Specifically, 7 out of 10 bands excised from DGGE were identified as Thauera sp., which are heterotrophic denitrifiers. This genus can also produce extracellular polymers that promote granulation [28]. Since Thauera is the most common bacteria found in both activated and granular sludge, the dominance of this species in granules indicates that Thauera could be selected and enriched from the inoculums due to its good aggregation capability under short settling time. Bands 1, 4 and 6 were identified as Hydrogenophaga, Acidovorax, and Leadbetterella, respectively. Hydrogenophaga is a facultative autotroph using $\mathrm{CO}_{2}$ as a carbon source. It was found to be closely related to the dehydrogenase activity and the secretion of EPS in the ampicillin wastewater treatment process [29]. This suggests from another aspect that the three-dimensional structure of granules and its high biomass retention capability enable the retention of extremely slow-growing autotrophs in granular sludge, which might be difficult in suspended sludge. The diversity of the microbial population in granular sludge was thus increased for better performance. Acidovorax is a facultative denitrifier, which was reported to be present in wastewater with a low COD concentration, such as $300 \mathrm{mg} / \mathrm{L}$ [30]. Leadbetterella is a strictly aerobic bacterium and has a great ability to degrade biopolymers, such as EPS, in granules and, thus, result in the instability of granules. Luo et al. (2014) found the presence of Leadbetterella when the granules were broken into pieces under a low $\mathrm{C} / \mathrm{N}$ ratio such as 1 [11]. However, the presence of Leadbetterella in granules is not necessary to cause instability of the granules immediately. For example, in this study, the disintegration of granules occurred after day 140, while Leadbetterella was identified on day 85.

On day 227, the granules were reformed after the disintegration. The microbial compositions in the granules were much more diverse, and their relative abundance distribution was even more than those recorded on day 85, according to DGGE analysis. Like the granules on day 85 , the heterotrophic denitrifier Thauera was the most abundant genus. However, the bands representing Thauera decreased from 7 to 3. Hyphomicrobium (band 11) showed up as another type of dominant denitrifying bacterium in the granules. Li et al. (2015) reported that Hyphomicrobium could maintain granule structure and improve the formation and maturation of nitrifying granules. Novosphingobium (band 4) and Sphingopyxis (band 6) are the second abundant genera. They both belong to the four subdivisions of Sphingomonas, which is aerobic and has great ability in EPS production for structure stabilization. Recently, Sphingomonas was reported to have a good ability to remove ammonium through heterotrophic ammonium and nitrite assimilation [31]. As the second dominant microorganisms (2 bands), Sphingomonas replaced some of Thauera species, indicating that it is more robust in adapting to unstable conditions in low COD/N ratio wastewater. Nitrosomonas (band 2) was also present in the granules in the wastewater with a low $\mathrm{COD} / \mathrm{N}$ ratio. As a kind of autotrophic slow-growing bacterium, it oxidizes ammonium to nitrite. It is present especially in wastewater with high levels of ammonium nitrogen compounds. The slow-growing Nitrosomonas presence in the granules benefits granule stability. Actinobateria (band 1), Bdellovibrio (band 3), and "uncultured Saprospiraceae" (band 5) are all aerobic heterotrophic. Actinobateria is aerobic and notably known for its capacity to degrade complex polysaccharides [32]. It is reported to have the potency to produce secondary metabolites and enzymes, which is one of the main factors essential for environmental stress tolerance [33]. Bdellovibrio is obligating aerobic and can prey on bacteria and degrade $\mathrm{COD}$ and ammonium in wastewaters. Its presence indicates a cleaner water environment and a high system treatment capacity. Band 5 is "uncultured Saprospiraceae". Genus from Saprospiraceae is normally helical filaments. They are aerobic and have a demonstrated ability for the hydrolysis and utilization of complex carbon sources. The presence of Saprospiraceae might show the importance of the bonding role of filamentous bacteria in the re-granulation process of the disintegrated granules.

The microbial community of the granules at the phylum level was also different on the two days studied. Although the dominant phyla were Proteobacteria and Bacteroidetes on both days, the number of bacteria belonging to Bacteroidetes was 3 on day 227 and 1 
on day 85. Proteobacteria and Bacteroidetes play important roles in wastewater treatment in both aerobic and anaerobic sludge systems. Proteobacteria were reported as the most important phylum adaptive to various wastewater treatment conditions due to their rich strains and diversity of metabolic pathways. Bacteroidetes were associated with settling ability and the granular structure of aerobic granular sludge. Wang et al. (2017) reported that the abundance of Bacteroides decreased when the aerobic granular sludge disintegrated in a toxic ampicillin treatment system [29]. The increment in Bacteroidetes in this study suggests that the aerobic granules after re-granulation might be more stable than before the disintegration.

From the discussion above, it appears that the reformed granules had a different microbial community structure that might be more stable compared with that of the aerobic granules formed directly from the suspended sludge.

\subsection{The Disintegration and Re-Establishment of the Aerobic Granules under Identical Operation Conditions}

How to maintain the long-term structural stability of granules is critical for the stable operation of granular sludge-based reactors. Although no operational conditions were changed in this study, the disintegration of granules was observed after they were formed after a certain period and then reformed again. This indicates that the critical factor for granulation was still applied to the reactor, but the critical factor for the maintenance of the long-term stability of granules was varied. Liu and Tay (2015) reported that the optimal conditions for the granulation and maintenance of long-term stability of granules were different [8]. Thus, it is very imperative to investigate the critical factors for long-term stability to guide the stable operation of aerobic granules-based reactors.

After the formation of aerobic granules, granules size and biomass concentration increased from days 80 to 140 due to the retention of granules in the reactor, which can affect oxygen penetration depth in granules and the biomass loading rate (i.e., F/M ratio). In this study, granule size was smaller than $500 \mu \mathrm{m}$, which is relatively less likely to cause oxygen limitation in granules with sufficient aeration [34]. Unlike some reports [35], no obligate anaerobic microorganisms were identified in the granules, which could support the speculation of no oxygen limitation in granules. F/M ratios, however, varied significantly, as shown in Figure 6. It can be seen that the F/M ratio increased to $3.54 \mathrm{~g}$ COD/g MLVSS. $\mathrm{d}$ when $\mathrm{SVI}_{30}$ reached the highest and biomass reached the lowest values (Figure 1) on day 34 when suspended sludge was gradually transformed into granular sludge. Then, $\mathrm{SVI}_{30}$ decreased and the granules became dominant on day 80 , corresponding to the $\mathrm{F} / \mathrm{M}$ ratios decreasing from 3.54 to $1.0 \mathrm{gCOD} / \mathrm{gVSS} \cdot \mathrm{d}$ from day 40 to day 80 due to the excellent retention of aerobic granular sludge in the reactor. From day 80 to day 140, the F/M ratios were further reduced from 1.0 to $0.23 \mathrm{gCOD} / \mathrm{gVSS} \cdot \mathrm{d}$ due to increased biomass concentration and constant organic loading rate, indicating that the biomass loading ratio decreased. When F/M decreased to $0.23 \mathrm{gCOD} / \mathrm{gVSS} \cdot \mathrm{d}$ on day 140 , the disintegration and deterioration of the granular sludge were overserved, causing biomass washout and less biomass retention in the reactor and, thus, higher F/M again. Concurrently, a large number of protozoans appeared, and their number also experienced an increase and decrease with F/M decrease and increase accordingly from day 140 to day 210, as shown in Figure 7. As reported in [36], in modern wastewater treatment systems, where there is a low-load and high-sludge retention time, the presence of protozoa such as ciliates, flagellates, and amoebae, or even small metazoa, is very common. Peyong et al. (2012) found that protozoans in granules disappeared when OLR increased from 0.13 to $0.6 \mathrm{~kg} / \mathrm{m}^{3} \cdot \mathrm{d}$ [37]. In this study, there was no change of OLR, but the change in biomass concentration caused a change in the biomass loading rate (i.e., F/M); thus, the change in the number of protozoans might be one of the direct contributors to cause granule disintegration due to the damage of granular structure by predation from protozoans. As shown in Figure 7, after re-establishment or re-formation of the granules with increased F/M, no obvious protozoans were observed in the granules on day 245 . This cannot be 
explained by coincidence, and the most reasonable explanation is that the presence of protozoans depends on F/M rather than OLR.

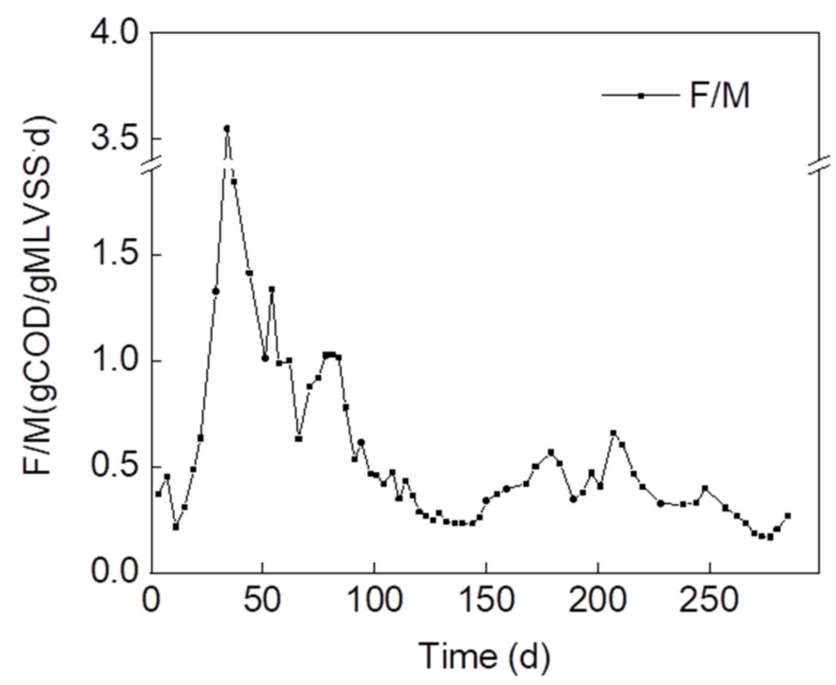

Figure 6. F/M ratios in the reactor during the long-term operation period.
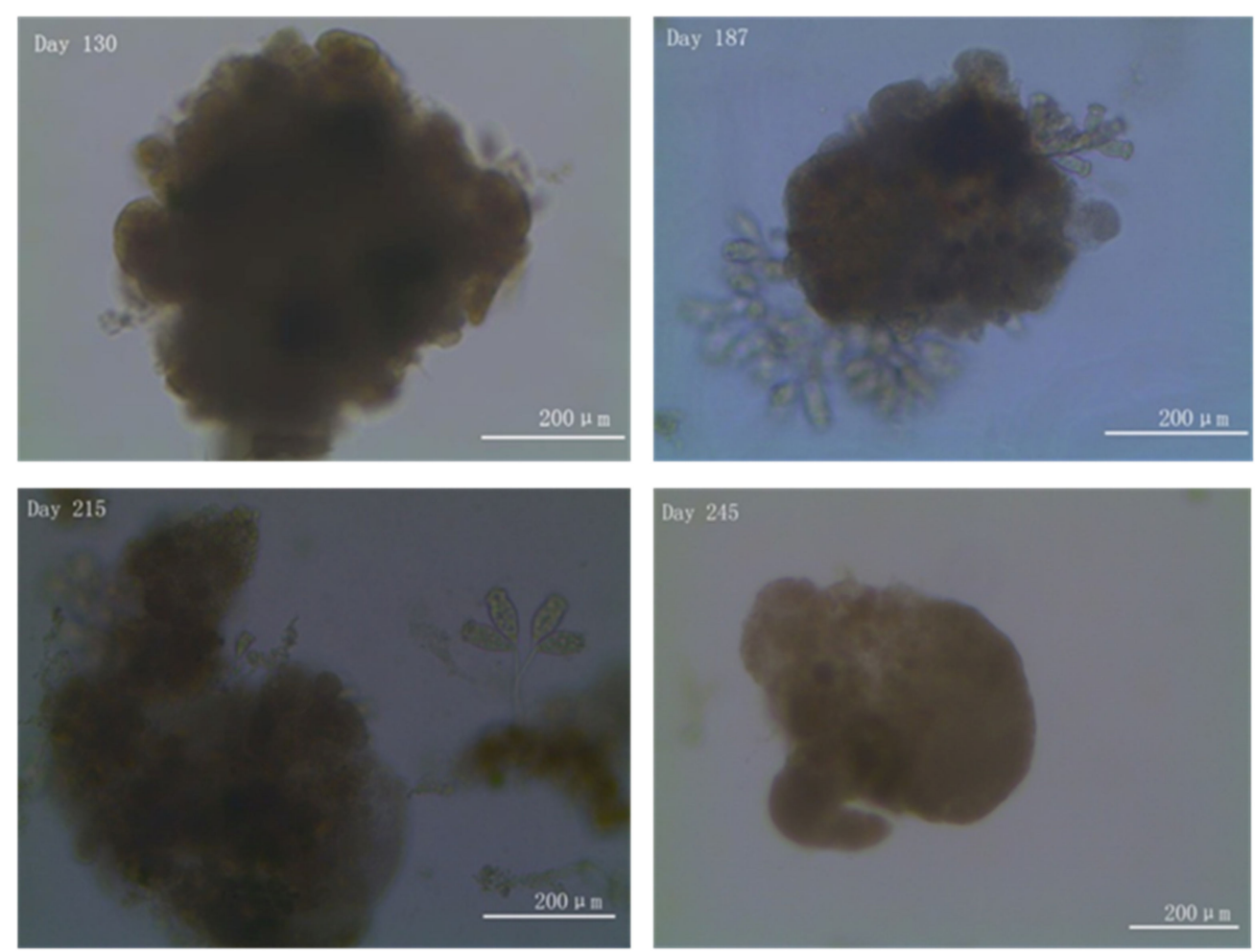

Figure 7. Morphologies of the aerobic granules on different operation days.

MLVSS began to increase from day 190, suggesting the improved sludge-settling ability of sludge. When the F/M ratio increased to $0.61 \mathrm{gCOD} / \mathrm{gVSS} \cdot \mathrm{d}$ on day 210 , the mean size of the granules began to increase again, and re-granulation took place. Therefore, it can be concluded that the lower biomass loading rate is unfavorable to the stability of granular sludge, while the increased biomass loading rate can stimulate the re-granulation. Controlling the biomass loading rate or $\mathrm{F} / \mathrm{M}$ ratio is, thus, critical to maintaining the long-term stability of granules at the conditions investigated in this study. There are also some other studies that reported the importance of $\mathrm{F} / \mathrm{M}$; however, the question of what level of F/M ratio should be maintained remains a challenge. Liu et al. (2004) reported 
that slow-growing bacteria could enhance the stability of granules; thus, granule stability is also related to levels of nutrients in wastewater [17]. It is also reported that feast/famine is critical to the stability of granules [38]. Since so many factors intervene with each other and affect the stability of granular sludge, it is challenging to propose a universal F/M ratio for the long-term stability of granules fed with different types of wastewater under different operational conditions. The results in this study revealed that $\mathrm{F} / \mathrm{M}$ ratios between 0.3 and $1.0 \mathrm{gCOD} / \mathrm{gVSS} \cdot \mathrm{d}$ helped maintain the long-term stability of aerobic granules for wastewater with a low-strength and low $\mathrm{C} / \mathrm{N}$ ratio. Although for different types of wastewater, the optimal F/M ratios for stability might be different, managing $\mathrm{F} / \mathrm{M}$ ratios in a certain range could improve the long-term stability of granular sludge. Reasonable F/M ratios could be maintained by manipulating biomass concentration to sustain stable aerobic granules during the long-term operation period. Wu et al. (2018) proposed an optimal $\mathrm{F} / \mathrm{M}$ via quantitative sludge discharge for the stability of aerobic granular process [39].

From the comparison, it can be seen that the F/M ratio for the formation of aerobic granules from activated sludge is almost twice the ratio of the re-granulation. This might be due to two different types of sludge that were involved in the granulation within the two periods, i.e., one was floccular-activated sludge for the granulation, and the other was disintegrated aerobic granular sludge for the re-granulation. The disintegrated aerobic granules by physical crushing as inoculum have been well proved to be easier to form into granules than the activated sludge. During this process, it should be noted that the recovery and enrichment of the microorganisms from day 190 to 200 is very essential for the re-graulation of the aerobic granules, which provides a foundation to this recovery.

In addition, it needs to be pointed out that the optimal $\mathrm{F} / \mathrm{M}$ ratios for the formation and long-term stability of granules should be different. Franca et al. (2018) reported that a higher $\mathrm{F} / \mathrm{M}$ ratio might favor the formation of granules, and a reduced ratio might help maintain stable granules [40]. They suggested that a loading rate of $2 \mathrm{gCOD} / \mathrm{gVSS} \cdot \mathrm{d}$ boosted the formation of aerobic granules, and a range of 0.3-0.6 gCOD / gVSS. $d$ enabled long-term stability of the granular system [14]. Our study reveals that under high ammonia concentrations (100 mgN/L) with the presence of nitrifying bacteria, COD loading could be higher but still maintain long-term structural stability. In particular, Figure 6 shows that the F/M increased to $3.54 \mathrm{gCOD} / \mathrm{gVSS} \cdot \mathrm{d}$ when MLSS decreased to $1.2 \mathrm{~g} / \mathrm{L}$ from day 30 to 80 , which supports the successful formation of the granules from activated sludge.

\section{Conclusions}

This study investigated the long-term stability of aerobic granular sludge in an SBR for treating synthetic wastewater with a $\mathrm{C} / \mathrm{N}$ ratio of 400:100 and low strength under alternating anoxic-oxic conditions for more than 300 days. The conclusions are summarized as follows:

- Aerobic granules were easily formed but experienced disintegration and re-granulation without any external intervention. The changes in granule size and biomass concentration during the operation period due to varying sludge-settling ability caused by the selective pressure and growing competition between flocs and granules altered environmental conditions sludge resided and, thus, granule stability.

- Although the sludge experienced a change in form from flocs to granules, granules to flocs, and flocs to granules again, the reactor performance in terms of COD removal and nitrification were almost stable.

- Aerobic granules formed from inoculated flocs (i.e., first granulation) and from flocs after granule disintegration had different dominant microbial populations. Moreover, Thauera, Sphingomonas, and other functional microorganisms were dominant in the re-granulated sludge. This indicates there was a dynamic microbial community structure of sludge in the reactor but with a relatively stable performance regarding wastewater treatment.

- $\quad \mathrm{F} / \mathrm{M}$ varied significantly due to the changes in biomass concentration caused by strong selective pressure and the change in sludge-settling ability in the reactor. F/M ratios 
should be controlled between 0.3 and $1.0 \mathrm{gCOD} / \mathrm{gSS} \cdot \mathrm{d}$ to maintain the stable structure of granules to minimize the fluctuation of sludge properties under the conditions used in this study.

Author Contributions: Writing—original draft preparation, L.C., Y.-Q.L. and F.C.; conceptualization, Y.-Q.L. and F.C.; methodology, L.C., W.D. and F.C.; validation, C.E.W.S.; supervision, F.C. and W.D.; data analysis, L.C. and Q.Y.; review and editing, Y.-Q.L., C.E.W.S. and F.C. All authors have read and agreed to the published version of the manuscript.

Funding: This work was funded by the National Nature Science Foundation of China, grant numbers 41763016, 41703121, and 41807377.

Conflicts of Interest: The authors declare no conflict of interest.

\section{References}

1. Arrojo, B.; Mosquera-Corral, A.; Garrido, J.M.; Méndez, R. Aerobic granulation with industrial wastewater in sequencing batch reactors. Water Res. 2004, 38, 3389-3399. [CrossRef] [PubMed]

2. Yang, S.-F.; Tay, J.-H.; Liu, Y. Respirometric Activities of Heterotrophic and Nitrifying Populations in Aerobic Granules Developed at Different Substrate N/COD Ratios. Curr. Microbiol. 2004, 49, 42-46. [CrossRef]

3. Jiang, H.-L.; Tay, J.-H.; Tay, S.-L. Aggregation of immobilized activated sludge cells into aerobically grown microbial granules for the aerobic biodegradation of phenol. Lett. Appl. Microbiol. 2002, 35, 439-445. [CrossRef]

4. $\quad$ Beun, J.; Hendriks, A.; van Loosdrecht, M.; Morgenroth, E.; Wilderer, P.; Heijnen, J. Aerobic granulation in a sequencing batch reactor. Water Res. 1999, 33, 2283-2290. [CrossRef]

5. Deng, S.; Ting, Y.-P. Characterization of PEI-modified biomass and biosorption of $\mathrm{Cu}(\mathrm{II}), \mathrm{Pb}(\mathrm{II})$ and Ni(II). Water Res. 2005, 39, 2167-2177. [CrossRef]

6. Zhou, Y.; Pijuan, M.; Yuan, Z. Development of a 2-sludge, 3-stage system for nitrogen and phosphorous removal from nutrient-rich wastewater using granular sludge and biofilms. Water Res. 2008, 42, 3207-3217. [CrossRef] [PubMed]

7. Qin, L.; Tay, J.-H.; Liu, Y. Selection pressure is a driving force of aerobic granulation in sequencing batch reactors. Process Biochem. 2004, 39, 579-584. [CrossRef]

8. Liu, Y.-Q.; Tay, J.-H. Fast formation of aerobic granules by combining strong hydraulic selection pressure with overstressed organic loading rate. Water Res. 2015, 80, 256-266. [CrossRef] [PubMed]

9. Liu, Y.; Liu, Q.-S. Causes and control of filamentous growth in aerobic granular sludge sequencing batch reactors. Biotechnol. Adv. 2006, 24, 115-127. [CrossRef]

10. Liu, Y.-Q.; Tay, J.-H. The competition between flocculent sludge and aerobic granules during the long-term operation period of granular sludge sequencing batch reactor. Environ. Technol. 2012, 33, 2619-2626. [CrossRef]

11. Luo, J.; Hao, T.; Wei, L.; Mackey, H.R.; Lin, Z.; Chen, G.-H. Impact of influent COD/N ratio on disintegration of aerobic granular sludge. Water Res. 2014, 62, 127-135. [CrossRef]

12. Long, B.; Yang, C.-Z.; Pu, W.-H.; Yang, J.-K.; Liu, F.-B.; Zhang, L.; Zhang, J.; Cheng, K. Tolerance to organic loading rate by aerobic granular sludge in a cyclic aerobic granular reactor. Bioresour. Technol. 2015, 182, 314-322. [CrossRef] [PubMed]

13. Liu, Y.; Tay, J.-H. State of the art of biogranulation technology for wastewater treatment. Biotechnol. Adv. 2004, 22, 533-563. [CrossRef]

14. Lee, D.-J.; Chen, Y.-Y.; Show, K.-Y.; Whiteley, C.G.; Tay, J.-H. Advances in aerobic granule formation and granule stability in the course of storage and reactor operation. Biotechnol. Adv. 2010, 28, 919-934. [CrossRef] [PubMed]

15. Alias, M.A.; Muda, K.; Affam, A.C.; Aris, A.; Hashim, N. The effect of divalent and trivalent cations on aggregation and surface hydrophobicity of selected microorganism. Environ. Eng. Res. 2016, 22, 61-74. [CrossRef]

16. Claude, V.; Mahy, J.G.; Tilkin, R.G.; Lambert, S.D. Enhancement of the catalytic performances and lifetime of $\mathrm{Ni} / \gamma-\mathrm{Al}_{2} \mathrm{O}_{3}$ catalysts for the steam toluene reforming via the combination of dopants: Inspection of $\mathrm{Cu}, \mathrm{Co}, \mathrm{Fe}, \mathrm{Mn}$, and Mo species addition. Mater. Today Chem. 2020, 15, 100229. [CrossRef]

17. Liu, Y.; Yang, S.-F.; Tay, J.-H. Improved stability of aerobic granules by selecting slow-growing nitrifying bacteria. J. Biotechnol. 2004, 108, 161-169. [CrossRef] [PubMed]

18. De Kreuk, M.; Heijnen, J.; van Loosdrecht, M. Simultaneous COD, nitrogen, and phosphate removal by aerobic granular sludge. Biotechnol. Bioeng. 2005, 90, 761-769. [CrossRef]

19. Pronk, M.; de Kreuk, M.; de Bruin, B.; Kamminga, P.; Kleerebezem, R.; van Loosdrecht, M. Full scale performance of the aerobic granular sludge process for sewage treatment. Water Res. 2015, 84, 207-217. [CrossRef]

20. Yang, S.-F.; Tay, J.-H.; Liu, Y. Effect of Substrate Nitrogen/Chemical Oxygen Demand Ratio on the Formation of Aerobic Granules. J. Environ. Eng. 2005, 131, 86-92. [CrossRef]

21. De Kreuk, M.; Van Loosdrecht, M. Selection of slow growing organisms as a means for improving aerobic granular sludge stability. Water Sci. Technol. 2004, 49, 9-17. [CrossRef] 
22. Yang, S.-F.; Tay, J.-H.; Liu, Y. Inhibition of free ammonia to the formation of aerobic granules. Biochem. Eng. J. 2004, 17, 41-48. [CrossRef]

23. Chen, F.-Y.; Liu, Y.-Q.; Tay, J.-H.; Ning, P. Rapid formation of nitrifying granules treating high-strength ammonium wastewater in a sequencing batch reactor. Appl. Microbiol. Biotechnol. 2015, 99, 4445-4452. [CrossRef] [PubMed]

24. Wei, D.; Qiao, Z.; Zhang, Y.; Hao, L.; Si, W.; Du, B.; Wei, Q. Effect of COD/N ratio on cultivation of aerobic granular sludge in a pilot-scale sequencing batch reactor. Appl. Microbiol. Biotechnol. 2012, 97, 1745-1753. [CrossRef] [PubMed]

25. Wu, L.; Peng, C.; Peng, Y.; Li, L.; Wang, S.; Ma, Y. Effect of wastewater COD/N ratio on aerobic nitrifying sludge granulation and microbial population shift. J. Environ. Sci. 2012, 24, 234-241. [CrossRef]

26. Kocaturk, I.; Erguder, T.H. Influent COD/TAN ratio affects the carbon and nitrogen removal efficiency and stability of aerobic granules. Ecol. Eng. 2016, 90, 12-24. [CrossRef]

27. Liu, Y.-Q.; Moy, B.; Kong, Y.-H.; Tay, J.-H. Formation, physical characteristics and microbial community structure of aerobic granules in a pilot-scale sequencing batch reactor for real wastewater treatment. Enzym. Microb. Technol. 2010, 46, 520-525. [CrossRef]

28. Cydzik-Kwiatkowska, A.; Bernat, K.; Zielinska, M.; Wojnowska-Baryła, I. Cycle length and COD/N ratio determine properties of aerobic granules treating high-nitrogen wastewater. Bioprocess Biosyst. Eng. 2013, 37, 1305-1313. [CrossRef]

29. Wang, L.; Deng, S.; Wang, S.; Su, H. Analysis of aerobic granules under the toxic effect of ampicillin in sequencing batch reactors: Performance and microbial community. J. Environ. Manag. 2017, 204, 152-159. [CrossRef]

30. Ma, J.; Quan, X.; Li, H. Application of high OLR-fed aerobic granules for the treatment of low-strength wastewater: Performance, granule morphology and microbial community. J. Environ. Sci. 2013, 25, 1549-1556. [CrossRef]

31. Yun, L.; Yu, Z.; Li, Y.; Luo, P.; Jiang, X.; Tian, Y.; Ding, X. Ammonia nitrogen and nitrite removal by a heterotrophic Sphingomonas sp. strain LPN080 and its potential application in aquaculture. Aquaculture 2019, 500, 477-484. [CrossRef]

32. Vijayalayan, P.; Thanh, B.X.; Visvanathan, C.; Bui, X.-T. Simultaneous nitrification denitrification in a Batch Granulation Membrane Airlift Bioreactor. Int. Biodeterior. Biodegrad. 2014, 95, 139-143. [CrossRef]

33. Bankar, A.; Nagaraja, G. Chapter 18-Recent Trends in Biosorption of Heavy Metals by Actinobacteria. In New and Future Developments in Microbial Biotechnology and Bioengineering; Singh, B.P., Gupta, V.K., Passari, A.K., Eds.; Elsevier: Amsterdam, The Netherlands, 2018; pp. 257-275.

34. Liu, Y.; Tay, J.-H. Relationship between size and mass transfer resistance in aerobic granules. Lett. Appl. Microbiol. 2005, 40, 312-315. [CrossRef] [PubMed]

35. Tay, J.-H.; Ivanov, V.; Pan, S.; Tay, S.T.-L. Specific layers in aerobically grown microbial granules. Lett. Appl. Microbiol. 2002, 34, 254-257. [CrossRef] [PubMed]

36. Madoni, P. Protozoa in wastewater treatment processes: A minireview. Ital. J. Zool. 2011, 78, 3-11. [CrossRef]

37. Peyong, Y.N.; Zhou, Y.; Abdullah, A.Z.; Vadivelu, V. The effect of organic loading rates and nitrogenous compounds on the aerobic granules developed using low strength wastewater. Biochem. Eng. J. 2012, 67, 52-59. [CrossRef]

38. Corsino, S.F.; di Biase, A.; Devlin, T.R.; Munz, G.; Torregrossa, M.; Oleszkiewicz, J.A. Effect of extended famine conditions on aerobic granular sludge stability in the treatment of brewery wastewater. Bioresour. Technol. 2017, 226, 150-157. [CrossRef]

39. Wu, D.; Zhang, Z.; Yu, Z.; Zhu, L. Optimization of F/M ratio for stability of aerobic granular process via quantitative sludge discharge. Bioresour. Technol. 2018, 252, 150-156. [CrossRef]

40. Franca, R.D.; Pinheiro, H.M.; van Loosdrecht, M.C.; Lourenço, N.D. Stability of aerobic granules during long-term bioreactor operation. Biotechnol. Adv. 2018, 36, 228-246. [CrossRef] 